\title{
Bursaphelenchus Fuchs, 1937 (Nematoda: Parasitaphelenchidae) species associated with Pinus species in northern Turkey
}

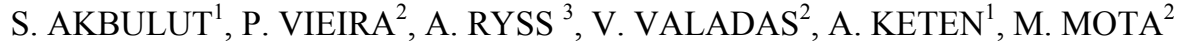

\begin{abstract}
${ }^{1}$ Düzce University, Orman Fakultesi, Konuralp Kampusu, 81620 Düzce, Turkey, E-mail: akbulutsuleyman@yahoo.com; ${ }^{2}$ NemaLab/ICAM, Universidade de Évora, 7002-554 Évora, Portugal; E-mail: pvieira@uevora.pt; ${ }^{3}$ Zoological Institute RAS, Univeritetskaya Naberezhnaya 1, St. Petersburg 199034, Russia, E-mail:nema@zin.ru
\end{abstract}

\begin{abstract}
Summary
A survey for Bursaphelenchus nematodes, associated with different conifer trees, was conducted in several forest areas in the northern regions of Turkey. Only pine trees (Pinus nigra, P. pinaster and P. sylvestris) yielded Bursaphelenchus specimens. Nematodes were identified using several morphological diagnostic characters of the genus (male spicule structure, number of lateral incisures, number and distribution of the male papillae, presence of female vulval flap), and confirmed by using RFLP analysis of the internal transcriber spacer (ITS) regions of ribosomal DNA. Three different species were identified from several sampled areas, namely $B$. mucronatus, B. pinophilus and $B$. sexdentati, representing a first report of the last two species for Turkey. The association of $B$. pinophilus with black pine ( $P$. nigra) is herein reported for the first time.
\end{abstract}

Key words: Bursaphelenchus spp.; pine trees; morphology; ITS-RFLP analysis

\section{Introduction}

Within the past seven years, special relevance and attention has been given to the genus Bursaphelenchus, Fuchs 1937 particularly in European countries. The official measures imposed by the European Union force each country to proceed with national surveys to prevent the introduction of the pine wood nematode, Bursaphelenchus xylophilus (Steiner \& Buhrer, 1934) Nickle, 1970. The enforcement of these measures is a direct result of the first detection of this pathogenic species (A1 quarantine pest, according to EPPO) in Portugal, and in Europe (Mota et al., 1999). The need for prevention and detection of B. xylophilus, from endemic conifer forests, and in wood product trade, has increased the number of species recorded worldwide, especially within the European and Asiatic continents (Ryss et al., 2005).
In Turkey, a country that forms one of the boundaries between Europe and Asia, forest ecosystems play a very important role in the economy and occupy a considerable area ( $27 \%$ of the country's territory). Total forestry area consists of over 21 million ha, represented by $54 \%$ conifer trees, $36 \%$ broad-leaved trees, and $10 \%$ of mixed forest. Among conifers, four species of Pinus are predominant: the Turkish pine (P. brutia Ten.) spread mainly to the West and South West (Mediterranean region), covers an area of 5420524.6 ha; the Austrian pine (P. nigra Arnold) forming a forest of pure or mixed type, covers an area of 4 202298.2 ha, spread over the mountainous areas of all coastal regions; Scots pine ( $P$. sylvestris L.) in single or mixed forests, in the higher mountainous areas of North Anatolia and some areas in the inner and Southern regions, occupies an area of 1239578.2 ha; and Stone pine ( $P$. pinea L.), a typical Mediterranean species, covers an area of 42618.2 ha, mainly in West and Southern Anatolia (Critchfield \& Elbert, 1966; Anonymous, 2006).

Besides the broad area occupied by these indigenous species, other introduced pines occupy a representative area ( $P$. pinaster Aiton covers an area of 77091.7 ha, and $P$. radiata $D$. Don an area of $47 \mathrm{ha}$ ), as well as other indigenous species (Abies spp. occupying 626647.2 ha; Cedrus spp. occupying 417188.5 ha; Picea orientalis (L) Link. occupying 297396.5 ha and Juniperus spp. occupying 447 492.5 ha) (Anonymous, 2006). Despite the richness of the Turkish forest, the importation of industrial wood for consumption assumes special relevance, reaching almost 1 million $\mathrm{m}^{3}$ of imported coniferous wood in 1999 (Anonymous, 2001).

Until recently, little information was available for the genus Bursaphelenchus in Turkey, corresponding to several short reports of this genus (Vieira et al., 2003; Vieira et al., 2004). More recently two new species have been described, namely B. anatolius Giblin-Davis, Hazir, Center, Ye, Keskin, Thorp \& Thomas, 2005, associated with bees 
of the genus Halictus (Giblin-Davis et al., 2005), and B. anamurius Akbulut, Braasch, Baysal, Brandstetter \& Burgermeister, 2007, associated with Pinus brutia (Akbulut et al., 2007).

Due to the economic importance assumed by the PWN in Europe, associated with the large natural resources of Turkey, it was imperative to conduct some studies related to the species occurrence of this genus in the country. Therefore, a preliminary survey on the pinewood nematode was conducted in specific forest areas in the north of the country, special relevance being given to species belonging to the xylophilus-group of the genus Bursaphelenchus (Akbulut et al., 2006). During this survey, and besides $B$. mucronatus Mamiya \& Enda, 1979, several others specimens displaying morphological features of the genus Bursaphelenchus were collected but identified only at the genus level. In order to identify the species, further studies were carried out, and so a general morphological characterization (optical and scanning microscopy) and a molecular analysis (ITS-RFLP patterns) of the Bursaphelenchus species found in Turkey is provided in this paper.

\section{Material and methods}

\section{Wood sampling and nematode isolation}

In 2003 - 2004, a survey was conducted in the conifer forest areas of Ankara, Artvin, Düzce, Istanbul, Samsun and Trabzon, in Turkey (Fig. 1). Wood samples (40 - $80 \mathrm{~g}$ each) were collected from conifer trees (Abies spp., Cedrus spp., Picea spp. and Pinus spp.), displaying decline symptoms, at $1.5 \mathrm{~m}$ level of the trunk, using a drill and kept in polyethylene bags until nematode extraction. Nematodes were extracted using a modified Baermann funnel technique, and processed within $48 \mathrm{~h}$. For those samples with significant numbers, the nematodes were inoculated on Botrytis cinerea Pars., growing in malt agar, and incubated for 2 weeks at $25^{\circ} \mathrm{C}$.

\section{Morphological identification}

Nematodes obtained from successful fungal cultures were fixed with hot formalin (4\%), processed to anhydrous glycerin and mounted in permanent slides according to the "express technique" described by Ryss (2003), and identified using an optical microscope (Olympus BX50). For scanning electron microscope (SEM) observations, using a JEOL 35 SEM, adult nematodes were fixed in a mixture of $4 \%$ gluteraldehyde- $2 \%$ formaldehyde for $48 \mathrm{~h}$, post-fixed in $2 \% \mathrm{OsO}_{4}$ overnight, dehydrated in an ethanol series, followed by critical point drying and sputter coated with gold (Eisenback, 1985).

\section{Molecular identification}

From each fungal culture, $30-50$ nematodes were collected into a small drop of water, in a $1.5 \mathrm{ml}$ Eppendorf tube, and stored at $-20{ }^{\circ} \mathrm{C}$ for DNA analysis. The DNA extraction was carried out following Cenis (1993), with some modifications. After a brief centrifugation, $300 \mu \mathrm{l}$ of extraction buffer (200 mM Tris-HCl, pH 8.0; $250 \mathrm{mM} \mathrm{NaCl} ; 25 \mathrm{mM}$
EDTA, and $0.5 \%$ SDS) was added to the tube, and the nematodes were smashed with a conical pestle (Eppendorf). The lysate was incubated for 2 hours at $65{ }^{\circ} \mathrm{C}$. Then, 0.5 volume of $3 \mathrm{M}$ sodium acetate $(\mathrm{pH}$ 5.2) was added, and stored on ice for $20 \mathrm{~min}$. After centrifugation at 13000 $\mathrm{rpm}, 4^{\circ} \mathrm{C}$ for $15 \mathrm{~min}$, the supernatant was transferred to a new tube, the nucleic acids were precipitated with 1 volume of isopropanol at room temperature for $30 \mathrm{~min}$. and pelleted by centrifugation at $13000 \mathrm{rpm}$, at $4{ }^{\circ} \mathrm{C}$ during $15 \mathrm{~min}$. The pellet was washed in $500 \mu \mathrm{l}$ of $70 \%$ ethanol, centrifuge at $13000 \mathrm{rpm}$, at $4{ }^{\circ} \mathrm{C}$ during $10 \mathrm{~min}$, and redissolved in $40 \mu \mathrm{l}$ of TE buffer.

ITS-RFLP analysis was carried out following the method described in Hoyer et al. (1998). The ITS regions of rDNA were amplified using the forward primer 5'CGTAACAAGGTAGCTGTAG-3' (Ferris et al., 1993) and reverse primer 5'-TTTCACTCGCCGTTACTAAGG-3' (Vrain, 1993). All polymerase chain reactions were performed in a final volume of $50 \mu \mathrm{l}$, contained $1 \mathrm{x}$ reaction buffer (BIOPortugal), $1.5 \mathrm{mM} \mathrm{MgCl}_{2}, 0.1 \mathrm{mM}$ dNTP's (Invitrogene), $0.6 \mu \mathrm{M}$ of each primer (STABVIDA), $2 \mathrm{U}$ of Taq DNA polymerase (BIOPortugal) and 2 ng DNA. For amplification a thermocycler was used employing the following steps: one initial denaturation at $94{ }^{\circ} \mathrm{C}$ for $2.5 \mathrm{~min}$., 40 reaction cycles of $94^{\circ} \mathrm{C}$ for $1 \mathrm{~min} ., 55^{\circ} \mathrm{C}$ for $1 \mathrm{~min} ., 72$ ${ }^{\circ} \mathrm{C}$ for $2 \mathrm{~min}$., and a final extension at $72^{\circ} \mathrm{C}$ for $5 \mathrm{~min}$.

The restriction analysis of the ITS regions was performed with AluI, HaeIII, HinfI, MspI and RsaI restriction endonucleases, using an aliquot of $8.5 \mu \mathrm{l}$ of the PCR product and $10 \mathrm{U}$ of each enzyme. Fragments were resolved by electrophoresis in a $1.8 \%$ agarose gel and stained with ethidium bromide.

\section{Results}

\section{Species distribution}

A total of 358 wood samples were collected from several conifer species (cedar, fir, pine, spruce) for the presence of Bursaphelenchus nematodes, in different geographic areas in the northern part of the country (Fig. 1). The greatest number of wood samples was collected from $P$. nigra (118 samples) and $P$. sylvestris (159 samples), corresponding to the species with a higher number of symptomatic trees in the sampled forest areas. Although several nematodes species were present in high numbers of wood samples,

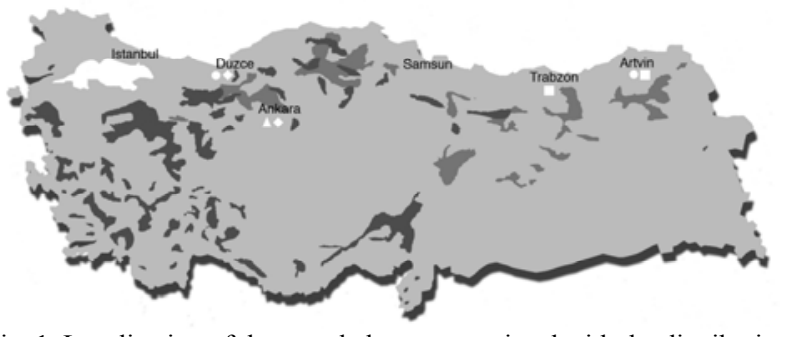

Fig. 1. Localization of the sampled areas associated with the distribution of the major pine species trees sampled (dark grey areas: . nigra; light grey areas: $P$. sylvestris), and distribution of Bursaphelenchus species.

$\circ:$ B. mucronatus; $\triangle:$ : B. pinophilus; $\diamond:$ B. sexdentati;

$\square:$ Bursaphelenchus specimens belonging to the sexdentati-group sensu Braasch (see text) 
only a few samples contained Bursaphelenchus nematodes reared only from pine trees. The geographic localization of the Bursaphelenchus isolates found during this survey (Fig. 1), and associated Pinus host, is summarized in Table 1.

Table 1. Host tree and localization of the Bursaphelenchus isolates found in north regions of Turkey.

\begin{tabular}{|c|c|c|c|}
\hline Bursaphelenchus sp. & $\begin{array}{c}\text { Isolate } \\
\text { code }\end{array}$ & Location & Host tree \\
\hline \multirow[t]{11}{*}{ B. mucronatus } & A-6 & Artvin & P. sylvestris \\
\hline & A-13 & Artvin & P. sylvestris \\
\hline & A-43 & Artvin & P. sylvestris \\
\hline & $A-50$ & Artvin & P. sylvestris \\
\hline & S-4 & Düzce & P. nigra \\
\hline & S-18 & Düzce & P. nigra \\
\hline & S-26 & Düzce & P. nigra \\
\hline & S-28 & Düzce & P. nigra \\
\hline & $13 \mathrm{Y}-\mathrm{K}$ & Düzce & P. nigra \\
\hline & $12-\mathrm{K}$ & Düzce & P. nigra \\
\hline & O-7 & Düzce & P. sylvestris \\
\hline B. pinophilus & $\mathrm{T}-\mathrm{I}$ & Ankara & P. nigra \\
\hline \multirow[t]{2}{*}{ B. sexdentati } & T-II & Ankara & P. nigra \\
\hline & S-12 & Düzce & $P$. pinaster \\
\hline \multirow[t]{3}{*}{ Bursaphelenchus sp. ${ }^{1}$} & A-14 & Artvin & P. sylvestris \\
\hline & A-58 & Artvin & P. sylvestris \\
\hline & $\mathrm{T}-47$ & Trabzon & P. sylvestris \\
\hline
\end{tabular}

${ }^{1}$ Due to the reduced number of specimens and slide conditions, the species identification was not achieved, and only the species group is mentioned.

\section{Morphological identification}

All Bursaphelenchus isolates were separated based on the spicule structure type, and assigned to one of the morpho- logical groups of species defined by Ryss et al. (2005) (Fig. 2 ), namely the xylophilus-group sensu Ryss et al. and the piniperdae-group sensu Ryss et al., in the last case, and to a more restricted number of species, assigned to the so called sexdentati-group sensu Braasch (2001).

Previously, the isolates belonging to the xylophilus-group were identified to species level, revealing the presence of $B$. mucronatus (Fig. 2F-I) from two sampled areas (Fig. 1) (Akbulut et al., 2006). No other specimens belonging to this group, including B. xylophilus, were found in the collected wood samples. All other specimens, identified as Bursaphelenchus sp. 1 and Bursaphelenchus sp. 2 (Akbulut et al., 2006), displayed the main diagnostic characters of the sexdentati-group sensu Braasch, i.e., four lateral lines, caudal papillae distributed as 1 single pre-anal, 1 pair adanal, and 2 pairs post-anal ( 1 before bursa, and 1 at the bursa), the typical spicules structure (spicules bent and relatively compact) (Fig. 2A), small vulval flap, with a protuberance behind vulva (Braasch, 2001). A more detailed morphological observation, based on the most important diagnostic characters (Table 2), confirmed the presence of two different species belonging to this group, namely B. pinophilus Brzeski \& Baujard, 1997 (Fig. 2C-E) and B. sexdentati Rühm, 1960 (Fig. 2A-B).

While isolate $\mathrm{T}-1$ conformed to the original morphological description of B. pinophilus (Brzeski \& Baujard, 1997), in the case of $B$. sexdentati (isolates T-II and S-12) some differences can be observed in certain characters comparing with the original description given by Rühm (1960), i.e., a female tail gradually tapering, conical conoid (Fig. 2C) vs. a tail less conoid and bluntly rounded end described in the original description, the presence of cucullus (Fig. 2B) vs. the absence of cucullus in the male spicules. However, these isolates show the same morphological differences

Table 2. Diagnostic morphological characters for Bursaphelenchus species occurring in Turkey.

\begin{tabular}{|c|c|c|c|c|c|}
\hline Species & Spicule structure & $\begin{array}{l}\text { Number } \\
\text { of lateral } \\
\text { incisures } \\
\end{array}$ & $\begin{array}{c}\text { Male caudal } \\
\text { papillae }\end{array}$ & $\begin{array}{l}\text { Female vulval } \\
\text { flap }\end{array}$ & Female tail \\
\hline B. mucronatus & $\begin{array}{l}\text { Spicule narrow, } \\
\text { capitulum flattened, } \\
\text { condylus small, lamina } \\
\text { angular in last third, } \\
\text { cucullus present }\end{array}$ & 4 & $\begin{array}{l}\text { Single ventral pre- } \\
\text { anal papilla, one } \\
\text { pair subventral } \\
\text { adanal, two post- } \\
\text { anal pairs }\end{array}$ & $\begin{array}{l}\text { Present, anterior } \\
\text { lip forming long } \\
\text { flap overlapping } \\
\text { vulva }\end{array}$ & $\begin{array}{c}\text { Subcylindrical, } \\
\text { rounded, tail tip } \\
\text { mucronate }\end{array}$ \\
\hline B. pinophilus & $\begin{array}{l}\text { Spicule stout, with well } \\
\text { developed rostrum, } \\
\text { variously shaped } \\
\text { condylus, with small } \\
\text { cucullus }\end{array}$ & 4 & $\begin{array}{l}\text { Single ventral pre- } \\
\text { anal papilla; one } \\
\text { pair sub-ventral } \\
\text { adanal; two post- } \\
\text { anal pairs }\end{array}$ & $\begin{array}{l}\text { Present, anterior } \\
\text { lip slightly } \\
\text { extended to form } \\
\text { small flap; post } \\
\text { vulval swelling } \\
\text { often present }\end{array}$ & $\begin{array}{l}\text { Tail conical } \\
\text { terminally } \\
\text { pointed, with } \\
\text { more or less } \\
\text { pronounced } \\
\text { mucron }\end{array}$ \\
\hline B. sexdentati & $\begin{array}{l}\text { Spicule stout, rostrum } \\
\text { sharply pointed, } \\
\text { condylus well developed, } \\
\text { broadly truncate, with } \\
\text { distinct small cucullus }\end{array}$ & 4 & $\begin{array}{l}\text { Single ventral pre- } \\
\text { anal papilla; one } \\
\text { pair sub-ventral } \\
\text { adanal; two post- } \\
\text { anal pairs }\end{array}$ & $\begin{array}{l}\text { Present, anterior } \\
\text { lip slightly } \\
\text { extended to form } \\
\text { small flap }\end{array}$ & $\begin{array}{l}\text { Tail gradually } \\
\text { tapering, conoid } \\
\text { with more or } \\
\text { less finely } \\
\text { rounded, } \\
\text { slightly blunt }\end{array}$ \\
\hline
\end{tabular}

\footnotetext{
${ }^{2}$ According to the original description of Rühm (1960), B. sexdentati does not possess a cucullus at the spicule tip. However, this morphological
} character is reported for B. sexdentati "South European" type (Lange et al., 2006). 

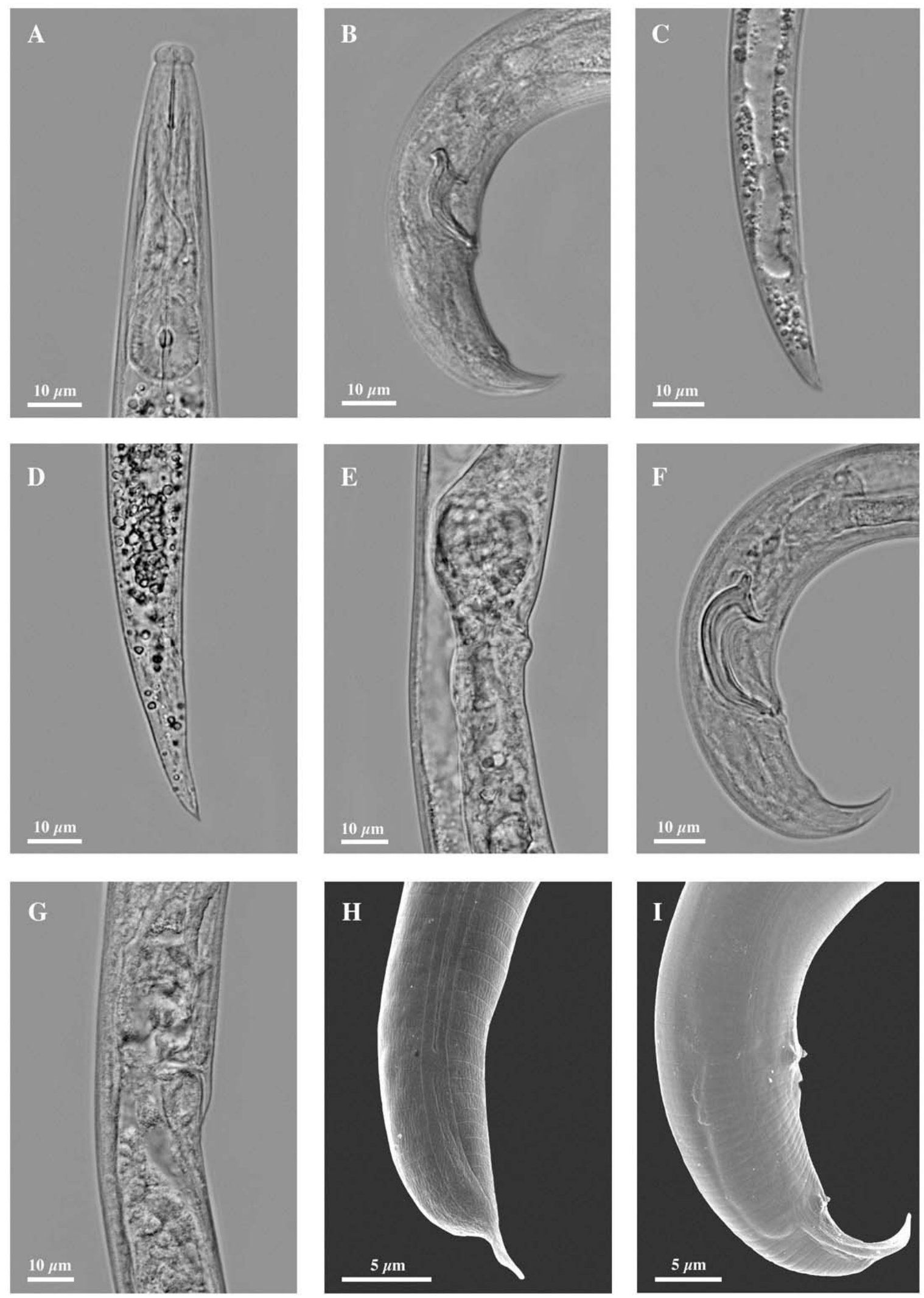

Fig. 2. Bursaphelenchus sexdentati (A-B) ${ }^{3}$. A: Light micrograph (LM) of male tail; B: LM of female tail. B. pinophilus (C-E). C: LM of vulva region; D: LM of male tail; E: LM of female tail. B. mucronatus (F-I). F: LM of male tail (spicule structure); G: LM of vulval region; $\mathrm{H}$ : Scanning electron micrograph (SEM) of female tail; I: SEM of male tail.

${ }^{3}$ These images do not correspond to the original morphological description of Rühm (1960), but to the morphological and molecular of B. sexdentati "South European" type (Lange et al., 2006). 
Table 3. Approximate size of DNA fragments observed in ITS-RFLP analysis of Bursaphelenchus species.

\begin{tabular}{|c|c|c|c|c|c|c|}
\hline \multirow[t]{2}{*}{ Bursaphelenchus sp. } & \multirow[t]{2}{*}{$\begin{array}{c}\text { PCR } \\
\text { product } \\
(\mathrm{bp})\end{array}$} & \multicolumn{5}{|c|}{$\begin{array}{l}\text { Restriction fragments } \\
\qquad(\mathrm{bp})\end{array}$} \\
\hline & & $R s a \mathrm{I}$ & HaeIII & MspI & HinfI & Alu $\mathrm{I}$ \\
\hline B. mucronatus & 950 & 410 & 620 & 370 & 410 & 700 \\
\hline \multirow[t]{3}{*}{ European type } & & 290 & 220 & 310 & 250 & 250 \\
\hline & & 230 & 110 & 280 & 130 & \\
\hline & & & & & $90^{*}$ & \\
\hline \multirow[t]{4}{*}{ B. pinophilus } & 1000 & 430 & 600 & 1000 & 400 & 1000 \\
\hline & & 340 & 280 & & 290 & \\
\hline & & 210 & $120 *$ & & 220 & \\
\hline & & & & & 90 & \\
\hline \multirow[t]{3}{*}{ B. sexdentati } & 1000 & 550 & 590 & 1000 & 470 & 1000 \\
\hline & & 410 & 280 & & 280 & \\
\hline & & & $120 *$ & & 210 & \\
\hline
\end{tabular}
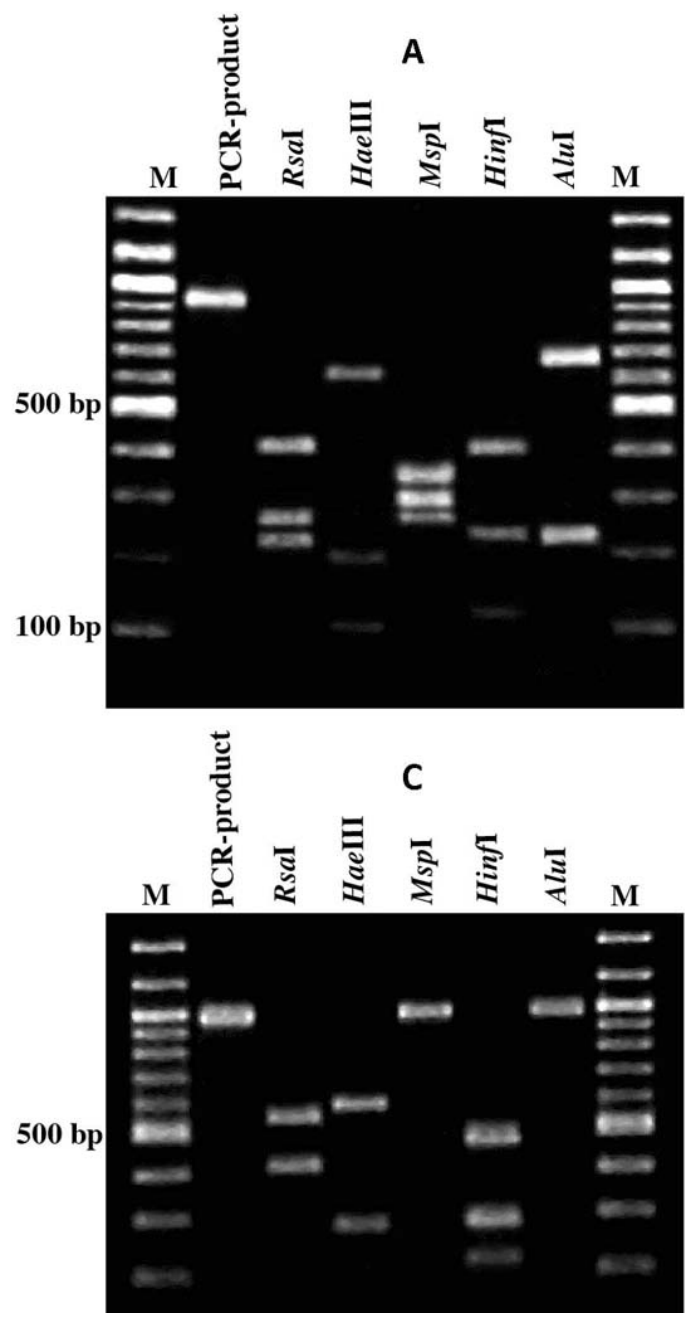

\footnotetext{
*Bands not clearly visible in the gels.
}

cited for other B. sexdentati isolates collected in Greece (Lange et al., 2006), Italy (Ambrogioni \& Caroppo, 1998) and Portugal (Penas et al., 2004).

Previously, isolates A-14, A-58 and T-47 were also classified as Bursaphelenchus sp. 2 (Akbulut et al., 2006), belonging to the sexdentati-group sensu Braasch. However, due to the limited number of specimens from each isolate (as well as the poor quality of the fixed material), and to the close morphological similarity among the species of this group, namely between $B$. sexdentati South-European type and $B$. vallesianus, the precise species identification was not clearly achieved, and therefore the occurrence of Bursaphelenchus specimens of the sexdentati-group sensu Braasch for these correspondent geographical areas is only mentioned.

\section{Molecular identification}

In order to complement and confirm the results obtained by morphological observations, a molecular analysis based on ITS-RFLP was performed, and the restriction patterns obtained were compared with the reference patterns established for the same species by Burgermeister et al. (2005).


Fig. 3. ITS-RFLP patterns of Bursaphelenchus species. A: B. mucronatus. B: B. pinophilus. C: B. sexdentati isolate T-12. D: $B$. sexdentati isolate S-12. The enzymes used for the restriction digest are indicated above the corresponding line. M: DNA size marker (100 bp). 
The ITS-RFLP profiles obtained confirm the morphological identification, revealing the presence of the three Bursaphelenchus species previously mentioned (Fig. 3 ). In the case of B. mucronatus (Table 3, Fig. 3A), the ITS-RFLP patterns obtained for the different geographic isolates reveal the European genotype of this species as shown by Burgermeister et al. (2005). Although isolate S-12 exhibits the same ITS-RFLP pattern as B. sexdentati, an additional weaker fragment of approximately $860 \mathrm{bp}$ was obtained for the Hae III restriction enzyme (Fig. 3D), comparable to the results achieved by Lange et al. (2006), for a $B$. sexdentati isolate [IT-2(w)] collected in Italy.

\section{Discussion}

The genus Bursaphelenchus is widely distributed over the North Hemisphere, associated with the conifer tree distribution, mainly pine species. The intense surveys for the pinewood nematode clearly emphasize our knowledge relating to the number and species distribution worldwide. After the detection of B. xylophilus in Portugal (Mota et al., 1999), up to thirty new species have been described for this genus, revealing high species diversity (Vieira et al., 2006). While most species have been found associated with pines, the detection of new species in other types of host trees (broadleaf trees) (Kanzaki \& Futai, 2005) and habitats (soil-dwelling bees, nitidulid beetles) (Giblin-Davis et al., 2005; Giblin-Davis et al., 2006) shows the high plasticity of the species that compose this genus. For detailed information on this subject see Ryss et al. (2005).

In Turkey, due to the large amount of forest resources (high biodiversity of suitable host species), associated with favorable biotic (insect vectors) and abiotic conditions (climate), the occurrence of a significant number of Bursaphelenchus species within the forest areas may be predictable. During this survey, three different species were found, constituting the first report and detailed description of these species for Turkey, although B. mucronatus has been previously reported (Akbulut et al., 2006).

Up to date, B. mucronatus is the species with the widest known distribution within the Euro-Asian continents (for a detailed species distribution see Ryss et al., 2005), and can be divided into two different types with regard to its genetic (ITS-RFLP) pattern (Burgermeister et al., 2005). Nevertheless, in Turkey only the European type was found, even when considering two extreme regions of the country, i.e. a more European area (Düzce) and an Asiatic area (Artvin).

Regardless of the importance of the morphological diagnostic characters to identify the different species-group, the high morphological similarity in some closely related species within a specific group (e.g. sexdentati-group sensu Braasch) could make identification at the species level difficult. The species that compose the sexdentati-group sensu Braasch, share a high level of morphological similarities, especially among $B$. pinophilus, B. sexdentati and $B$. vallesianus Braasch, Schönfeld, Polomski \& Burgermeister, 2004. In the case of B. pinophilus the morphological data obtained in this study follow the original descrip- tion of Brzeski \& Baujard (1997), and the same ITS-RFLP patterns published for this species (Burgermeister et al., 2005; Lange et al., 2006). The known distribution of this species is quite limited, reported only in Germany (Braasch, 2001), Poland (Brzeski \& Baujard, 1997) and Portugal (Penas et al., 2004). Although it has been reported to be associated with pine species ( $P$. sylvestris and $P$. pinaster), it had never been associated with black pine ( $P$. nigra).

On the other hand, $B$. sexdentati is one of the most wide spread species among the European continent, being the most frequently encountered Bursaphelenchus species in southern European countries. Regarding several studies where B. sexdentati has been reported (Ambrogioni \& Caroppo, 1998; Penas et al., 2004; Lange et al., 2006), this species shows a significant morphological variability when compared with other species of the genus (e.g. the shape of the female tail). Likewise, it has been shown that in some cases, specimens could be wrongly identified as $B$. sexdentati (Braasch et al., 2004). Recently, an integrated study postulated the differentiation of several $B$. sexdentati isolates in two major types, a "Central" and a "South" European types, based on both morphological and molecular analysis (ITS-RFLP with eight restriction enzymes, and sequence of the ITS regions) (Lange et al., 2006). Therefore, the original description of $B$. sexdentati showing a bluntly rounded female tail, male spicules with a less pointed rostrum, and without cucullus, correspond to the "Central European" type of this species (Lange et al., 2006), whereas the isolates herein reported (T-II and S-12) are closer to the morphology of the "South European" type, i.e., variable conoid female tail with more or less finely rounded, slightly blunt terminus, and the presence of a small cucullus at the male spicules.

The presence of the additional weak band in the profile generated by Hae III, in the isolate S-12, may be explained by some sequence heterogeneity of the ITS regions within this isolate, as has been recently shown for an Italian $B$. sexdentati isolate, where individuals or even the same specimen possess different ITS2 fragments, reflecting the appearance of minor bands in the ITS-RFLP patterns (Lange et al., 2006).

\section{Acknowledgements}

This research was partly supported by NATO (CLG97881), by the Scientific and Technological Research Council of Turkey (TUBITAK) and by Düzce University Scientific Research Project Commission. The authors would like to acknowledge Francisca Figo (NemaLabICAM, University of Évora) for laboratory assistance as well, ICAM ("Instituto de Ciências Agrárias Mediterrânicas") for material support through FCT ("Fundação para a Ciência e Tecnologia”) basic funding, and General Forestry Directorate of Turkey for field support.

\section{References}

Akbulut, S., Vieira, P., Ryss, A., Yuskel, B., Keten, A., 
Mota, M., Valadas, V. (2006): Preliminary survey of the pinewood nematode in Turkey. EPPO Bull., 36: 538 - 542 AKBulut, S., BraAsCH, H., Baysal, I., BrandstetTer, M., BURGERMEISTER, W. (2007): Description of Bursaphelenchus anamurius sp. n. (Nematoda: Parasitaphelenchidae) from Pinus brutia in Turkey. Nematology, 9: 859-867 Ambrogioni, L., CAROPPO, S. (1998): Morphology and morphometrics of Italian populations of Bursaphelenchus species. Nematol. Mediterr., 26: $97-116$

AnOnymous (2001): T. R. Prime Ministry State Planning Organization (DPT). Long-term strategy and Eight Fiveyear development Plan (2001-2005). Ankara, Turkey.

AnONYMous (2006): Turkey's Forests. General Directorate of Forestry, Republic of Turkey Ministry of Environment and Forestry, Ankara.

BRAASCH, H. (2001): Bursaphelenchus species in conifers in Europe: distribution and morphological relationships. EPPO Bull., 31: 127 - 142

BRAASCH, H., SCHÖNFELD, U., POLOMSKI, J., BURGERMEISTER, W. (2004): Bursaphelenchus vallesianus sp. n. - a new species of the Bursaphelenchus sexdentati group (Nematoda: Parasitaphelenchidae). Nematol. Mediterr., 32: 71 - 79 BRZESKI, M. W., BAUJARD, P. (1997): Morphology and morphometrics of Bursaphelenchus (Nematoda: Aphelenchoididae) species from pine wood of Poland. Ann. Zool., 47: $305-319$

Burgermeister, W., Metge, K., Braasch, H., BuchBACH, E. (2005): ITS-RFLP patterns for differentiation of 26 Bursaphelenchus species (Nematoda: Parasitaphelenchidae) and observations on their distribution. Russ. J. Nematol., 13: $29-42$

CENIS, J. L. (1993): Identification of four major Meloidogyne spp. by random amplified polymorphic DNA (RAPDPCR). Phytopathology, 83: $76-80$

CRITCHFIELD, W., LITTLE, E. (1966): Geographic distribution of the pines of the world. Miscellaneous Publication. U. S. Department of Agriculture, Forest Service.

EISENBACK, J. (1985): Techniques for preparing nematodes for scanning electron microscopy. In Barker, K. R., Carter, C. C. and Sasser, N. J. (Eds): An advanced treatise on Meloidogyne, Vol. II. Raleigh, NC, USA, North Carolina State University Graphics.

FERRIS, R. V., FERRIS, M. J., FAGHIHI, J. (1993): Variation in spacer ribosomal DNA in some cyst-forming species of plant parasitic nematodes. Fund. Appl. Nematol., 16: 177 - 184 FUCHS, A. G. (1937): Neue parasitische und halbparasitische Nematoden bei Borkenkäfern und einige andere Nematoden. I. Teil die Parasiten der Waldgartner Myelophilus piniperda L. und minor Hartig und die Genera Rhabditis Dujardin, 1845 und Aphelenchus Bastian, 1865. Zool. Jahrb. Abteil. Syst. Oek Geogr., 70: 291 - 380

Giblin-Davis, R., Hazir, S., Center, B. J., Ye, W., KesKIN, N., ThORP, R. W., ThOMAs, W. K. (2005): Bursaphe- lenchus anatolius n. sp. (Nematoda: Parasitaphelenchidae), an associate of bees in the genus Halictus. J. Nematol., 37: $336-342$

Giblin-Davis, R., KanZAKi, N., Ye, W., Mundo-OcAmpo, M., BALdwin, J. G., Thomas, W. K. (2006): Morphology and description of Bursaphelenchus platzeri n. sp. (Nematoda: Parasitaphelenchidae) an associate of nitidulid beetles. J. Nematol., 38: 150 - 157

Hoyer, U., Burgermeister, W., BraAsch, H. (1998): Identification of Bursaphelenchus species (Nematoda: Aphelenchoididae) on the basis of amplified ribosomal DNA (ITS-RFLP). Nachricht. Deutsch. Pflanzenschutz., 50: $273-277$

KANZAKI, N., FUTAI, K. (2005): Description of Bursaphelenchus parvispicularis n. sp. (Nematoda: Parasitaphelenchidae) isolated from a dead oak tree, Quercus mongolica var. grosseserrata. Nematology, 7: 751 - 759

Lange, C., Burgermeister, W., Metge, K., BraAsch, H. (2006): Phylogenetic analysis of isolates of the Bursaphelenchus sexdentati group using ribosomal intergenic transcribed spacer DNA sequences. J. Nem. Morph. Syst., 9: 95 - 109 Mota, M., Braasch, H., Bravo, M. A., Penas, A. C., Burgermeister, W., Metge, K., SousA, E. (1999): First report of Bursaphelenchus xylophilus in Portugal and in Europe. Nematology, 1: 727 - 734

Penas, A. C., Correia, P., Bravo, M. A., Mota, M. \& TENREIRO, R. (2004): Species of Bursaphelenchus Fuchs, 1937 (Nematoda: Parasitaphelenchidae) associated with maritime pine in Portugal. Nematology, 6: 437 - 453

RÜHM, W. (1960). Ein Beitrag zur Nomenklatur und Systematik einiger mit Scolytiden vergesellschafteter Nematodenarten. Zool. Anz., 164: 201 - 213

RYSS, A. (2003). Express technique to prepare permanent slides of nematodes. Zoosyst. Ross., 11: $257-260$

Ryss, A., Vieira, P., Mota, M., Kulinich, O. (2005): A synopsis of the genus Bursaphelenchus Fuchs, 1937 (Aphelenchida: Parasitaphelenchidae) with keys to species. Nematology, 7: 393 - 458

Vieira, P., Akbulut, S., Mota, M., Valadas, V. (2003): First report of Bursaphelenchus sp. from Turkey, associated with Pinus nigra. J. Nematol., 35: 369

Vieira, P., Valadas, V., Akbulut, S., Mota, M., Ryss, A. (2004): First report of Bursaphelenchus mucronatus from Turkey, associated with Pinus nigra. XXVII European Society of Nematologists International Symposium, Rome, 14-18 June 2004: programme and abstracts, p. 235 Vieira, P., Mota, M., Eisenback, J. (2006): Pinewood nematode taxonomic database. $2^{\text {nd }}$ Edition. Mactode Publications. (CD-ROM)

VRAIN, T. (1993): Restriction fragment length polymorphism separates species of Xiphinema americanum group. J. Nematol., 25: $361-364$ 